Ekonomia - Wroclaw Economic Review 26/2 (2020)

Acta Universitatis Wratislaviensis

No 3992

https://doi.org/10.19195/2658-1310.26.2.7

Alicja Sielska

ORCID: 0000-0002-0199-062X

University of Wrocław

alicja.sielska@uwr.edu.pl

Aleksandra Sielska

ORCID: 0000-0002-4311-3633

Wrocław University of Economics

aleksandra.krzykawiak@ue.wroc.pl

\title{
Quality of life of women: Selected results of direct research
}

Date of submission: 1.05.2020; date of acceptance: 20.06 .2020

JEL classification: I31, J16

Keywords: quality of life, happiness, well-being, women

Abstract

Quality of life of women: Selected results of direct research

This paper assesses the quality of life of women in Poland using a direct research method, namely a questionnaire carried out on a random sample of 503 people. The respondents were asked, first, to assess their own quality of life and, second, to evaluate specific factors such as wages, security, relationships with family, and forms of entertainment. We conclude that women in Poland highly and positively assess the majority of the analyzed components of quality of life. They pay the greatest attention to material issues as a result of Poland's postwar and postcommunist history.

\section{Introduction}

The term "quality of life" comes from many scientific disciplines, which include, among others, psychology, sociology, economics, medicine, pedagogy, and philosophy. This fact means that the literature on the subject defines the term in many ways. The variety of definitions is an effect of difficulty in formulating one concept including everything that makes up the quality of life of various communities and individuals (Borys, 2001). 
Quality of life concerns the self-fulfillment and functioning of individuals in such dimensions as the physical, psychological, and social (including occupational) (Kowalska, Marcinkowska, and Jośko, 2010). Scholars take three main philosophical approaches to the concept. The first approach describes the features of a good life dictated by normative ideals based on religious, philosophical, or other systems. The second approach is based on satisfying preferences, where quality of life depends on whether citizens are able to obtain the goods they want. The third approach considers the individual's perspective. The first approach is associated with social indicators in the social sciences, and the third with the tradition of subjective well-being in the behavioral sciences (Brock, 1993; Diener and Suh, 1997; Hajduová, Andrejovský, and Beslerová, 2014). Over the years, scholars have come to acknowledge that both objective and subjective factors are important. The former include material prosperity and access to infrastructure, while the latter include individuals' feelings, satisfaction, contentment, and happiness (Kędzior, 2003; Włodarczyk, 2015).

In Poland, the situation of women resembles that in the whole world. Women generally earn less than men, they hold lower positions in the occupational hierarchy, their unemployment rate is higher, they are less economically active, and so on. (Sielska, 2017, 57-92). Additionally, taking into account the ubiquity of neoclassical economics, in which individuals are usually seen in two roles (as sellers of labor and buyers of products) and profit and prices are the main determinants of their behavior (Duchin and Sinha, 1999), the study of gender differences is important, but neglected. Given this neglect, this paper addresses the following question: how do women in Poland perceive their quality of life, and what values are precious to them? To answer this question, we used our own survey, considering objective and subjective factors, to directly assess quality of life. ${ }^{1}$ We first explain the origin of the concept of quality of life in economics, then describe our methodology, and finally reach conclusions.

\section{Quality of life: genesis and development of the concept in economics}

The first attempts to answer questions about the quality of life can be found in ancient myths, religion, and philosophy. The ancient Greek philosophers looked for meaning and guidelines that would ultimately be useful in achieving a higher level of existence. This concept was considered by Aristotle and Plato, who had different opinions on the subject. The most important value for Plato was logical contemplation, which trumped human feelings. Aristotle claimed that life without feelings, even if it involves risk, is useless (Akranavičiūtè and Ruževičius, 2007). In ancient Greece, two concepts of happiness were distinguished: objective (it was

${ }^{1}$ Unlike the direct quality-of-life survey (questionnaire), one can assess it indirectly, using data from official statistics (Sompolska-Rzechuła, 2013; Kędzior, 2003). 
the most important good) and subjective (a joyful and intense experience) (Sompolska-Rzechuła, 2013). In the Middle Ages, the most influential writers on the subject were Saint Augustine and Saint Thomas Aquinas. Augustine said that happiness is possible only in the afterlife, while Aquinas believed that the goal of human striving is happiness, which means true knowledge of God (Michon', 2010).

Ancient and medieval philosophy was certainly the cornerstone of research on quality of life, but in economics the concept began ${ }^{2}$ with welfare economics, which was built on the doctrine of utilitarianism and developed at the end of the nineteenth century and the beginning of the twentieth century. Francis Edgeworth is considered the forerunner of welfare economics. He believed that prosperity depends only on the income of individuals and that social welfare is the sum of the utility of the income of individuals (Edgeworth, 1881). On the basis of these views, the concept arose of a fair distribution of wealth in a society in which there are no poor. Adam Smith, Jeremy Bentham, and John S. Mill (Kasprzyk, 2015) shared these views. Bentham, the creator of the calculus of happiness, believed that the leitmotiv of each person's action is to seek the greatest pleasure and that the measure for evaluating any such action must be human happiness (Bentham, 1958, 17-56). In turn, A. C. Pigou resolved the tension between individual utility and the utility of the whole society, where general well-being was for him the sum of the well-being of individuals (Pigou, 1920).

Welfare economics had its roots not only in neoclassical economics, but also the mathematical school of Lausanne, to which belonged, among others, Vilfredo Pareto. Pareto created the new concept of the welfare state and pointed out the conditions for optimal allocation of resources (Pareto, 1971; Persky, 1992). Welfare economics experienced a renaissance in the 1960s. At that time, it was striving to overcome the purely economic concept of economic growth. Many economists (among them Gunnar Myrdal, J.K. Galbraith, and Albert Hirschman) sought ways to quantify quality of life in order to achieve some kind of "social responsibility" (Veenhoven 1994). This approach to the study of the quality of life emphasizes mainly the objective and normative components of a good life, while the later happiness movement ${ }^{3}$ is characterized by a more subjective approach to evaluation (Bruni and Porta, 2016).

2 Earlier, when many basic needs were unmet, economic indicators were used to approximate how a nation was doing. However, as countries became richer and basic needs were largely met, standard indicators (e.g., GDP) lost their relevance. Furthermore, it could be seen that they are not synchronized with social well-being (e.g., the wealth of a given country has tripled with a significant increase in the proportion of mentally ill people) (Bruni and Porta, 2016). This situation was an impetus for further research on happiness and quality of life.

${ }^{3}$ For example, Amartya Sen proposes new approaches to the quality of life, which, according to him, should be based on living and not on possessing goods. This means that when examining the quality of life, new indicators should also be taken into account: democracy, social capital, health, rights, freedom, working conditions, and basic skills (Sen, 1970). 
Thus the criteria for defining quality of life as a non-economic good were identified in the $1920 \mathrm{~s}$, but raising quality of life did not become a social goal until the 1970s. Scholars paid attention to subjective (for example, life satisfaction and happiness) and objective (for example, material conditions, community, environmental protection) aspects of quality of life. These criteria were developed in the United States and then in Europe, respectively. U.S. scholars primarily emphasized subjective factors, while scholars in Europe (especially Scandinavia) emphasized objective life conditions (Glatzer, 2006). Many international organizations believe that both sides of the coin are extremely important and should not be overlooked. For example, the World Health Organization has emphasized both sides in its definition: "the way individuals perceive their position in life in the cultural context and the system of values in which they live, and in relation to their tasks, expectations and standards determined by environmental conditions. Thus, the quality of life is just a comprehensive way of assessing the individual's physical health, emotional state, independence in life and the degree of independence from the environment, as well as personal religious and nonreligious beliefs" (Tobiasz-Adamczyk, 1999).

Accordingly, we directly assess both subjective and objective criteria in this study.

\section{Research methodology}

In order to directly assess Polish women's perception of their quality of life, we used the quantitative method in the form of a questionnaire, a widely recognized method (Sompolska-Rzechuła, 2013; Kędzior, 2003). Unlike indirect sources originating from state statistics, whose cognitive and diagnostic value depends on whether tests on the same sample at various intervals can be repeated, questionnaires are characterized by the possibility of collecting facts, opinions, and assessments unavailable from other sources (Kędzior, 2003, 17). For our sample, we focus on a selected group of women. In line with international recommendations and practices and a rich tradition of Polish research, ${ }^{4}$ our questionnaire covered thematic areas such as wages, free time for recreation and personal development, relations with loved ones, health, and personal safety. We considered objective (remuneration level, types of entertainment, and personal development) and subjective (self-assessed well-being) factors. ${ }^{5}$

4 The largest collection on the quality of life of Polish society comes from data on household budgets and has been systematically kept since 1957 by the Central Statistical Office (GUS). In addition, an important source of information in this type of research in Poland is the National Census (Narodowy Spis Powszechny) and the so-called "micro-census" on representative samples. Surveys and interview methods belonging to primary (direct) sources of information are additional sources in quality-of-life research (Kędzior, 2003, 16-17).

5 Questionnaires should be included in the assessment of the quality of life in terms of value, which, however, in this case is reflected in an objective and subjective assessment. For example, 


\section{Results}

The survey was conducted on a random sample of women from Poland (503 women) between February 2017 and November 2018 with a prepared questionnaire. Table 1 depicts the characteristics of the respondents, including the proportions in various age groups. Of the total, 54 percent were without children, 50 percent single, 43 percent married, 69 percent with a university degree, and 66 percent living in a city with more than 100,000 inhabitants.

Table 1. Descriptive data of the studied group

\begin{tabular}{|c|c|c|c|}
\hline \multirow{2}{*}{ Name of variable } & \multirow{2}{*}{ Characteristics of variable } & \multicolumn{2}{|c|}{ Respondents } \\
\hline & & $\mathrm{n}$ & $\%$ \\
\hline Age & $\begin{array}{l}19-25 \\
26-35 \\
36-46 \\
46 \text { and over }\end{array}$ & $\begin{array}{r}164 \\
143 \\
83 \\
113\end{array}$ & $\begin{array}{l}33 \\
28 \\
17 \\
22\end{array}$ \\
\hline Number of children & $\begin{array}{l}1 \\
2 \\
3 \\
4 \\
\text { more than } 4 \\
\text { none }\end{array}$ & $\begin{array}{r}74 \\
108 \\
32 \\
12 \\
5 \\
272\end{array}$ & $\begin{array}{r}14 \\
21 \\
6 \\
2 \\
1 \\
54\end{array}$ \\
\hline Marital status & $\begin{array}{l}\text { single } \\
\text { married } \\
\text { divorced } \\
\text { widowed }\end{array}$ & $\begin{array}{r}250 \\
215 \\
29 \\
9\end{array}$ & $\begin{array}{r}50 \\
42 \\
6 \\
2\end{array}$ \\
\hline Education & $\begin{array}{l}\text { elementary } \\
\text { vocational } \\
\text { secondary } \\
\text { higher } \\
\text { other }\end{array}$ & $\begin{array}{r}3 \\
32 \\
115 \\
347 \\
6\end{array}$ & $\begin{array}{r}1 \\
6 \\
23 \\
69 \\
1\end{array}$ \\
\hline & city with over 100,000 residents & 334 & 65 \\
\hline & city with $50,000-100,000$ residents & 45 & 9 \\
\hline Place of residence & city with $10,000-49,999$ residents & 23 & 5 \\
\hline & city with less than 10,000 residents & 19 & 4 \\
\hline & village & 82 & 16 \\
\hline
\end{tabular}

Source: own research.

standard of living or living conditions translate into an objective picture of quality of life, and the perception of a standard of living is a subjective aspect of quality of life (Sompolska-Rzechuła, 2013, 131).

Ekonomia - Wroclaw Economic Review 26/, 2020

(C) for this edition by CNS 


\section{Polish women's perception of their quality of life}

In the first part of the survey, women were asked how they perceive their quality of life. The key question was "What do you think is an improvement of the quality of a woman's life?" According to the respondents, increases in personal earnings (33 percent) and better well-being and health (32 percent) have the highest impact (figure 1). Increases in expenditures on recreation and tourism have the lowest impact (11 percent). Respondents also indicated what other factors affect their quality of life. The most frequent answers were the feeling of being loved, good relations with loved ones, emotional maturity, equal treatment of women and men, better nutrition, having more free time, savings, professional fulfillment, career, promotion, and a happy family.
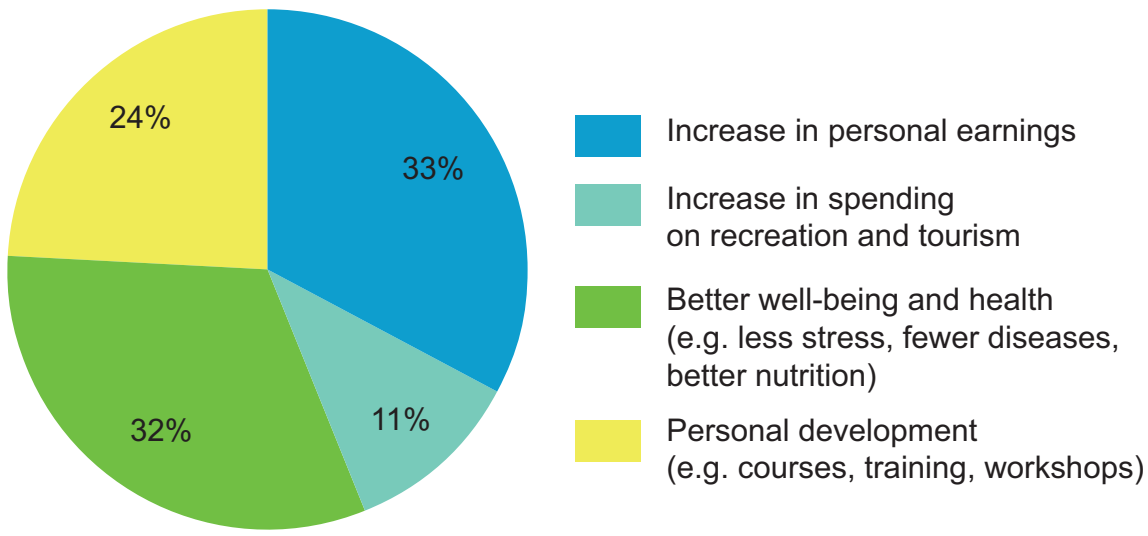

Figure 1. What do you think is an improvement in the quality of a woman's life? $(\mathrm{N}=1027)$

Source: own questionnaire.

In addition, women were asked to self-assess their quality of life. Most stated that it was very good (13 percent, or 64 people) or good (58 percent, or 294 people). Out of all respondents only 29 percent (145 people) evaluated their quality of life as not very good, as average, or as bad. They were mainly unemployed or earning less than PLN 3,000 net (26 percent from 29 percent).

\section{Evaluation of factors that represent quality of life}

In the next part of the questionnaire, we considered the factors explaining quality of life. We analyzed respondents' earnings in detail. The average net salary of the respondents is in the range PLN 2,000-5,000 net (55 percent, or 277 
people). ${ }^{6}$ Only 6 percent of respondents (30 people) earn over PLN 5,000 net, while fully 39 percent (197 people) earn less than PLN 2,000 net. Women with the lowest salaries (below PLN 2,000 net) are aged nineteen to twenty-five and have higher or secondary education, suggesting a relatively short participation in the labor market (usually they are working in their first job and have no professional experience), which may explain their low earnings. The majority of those who receive more than PLN 5,000 net are aged twenty-six to forty-six (78 percent). It is not surprising that the opinions on satisfaction with remuneration are so divided (after all, as many as 55 percent of respondents earn near the average nation-wide wage), with 46 percent of respondents satisfied and 54 percent dissatisfied. Of course, women dissatisfied with remuneration earn the least (55 percent of women with earnings less than PLN 2,000 net answered "I'm dissatisfied," as did 30 percent with earnings in the range of PLN 2,000-3,000 net; see figure 2).

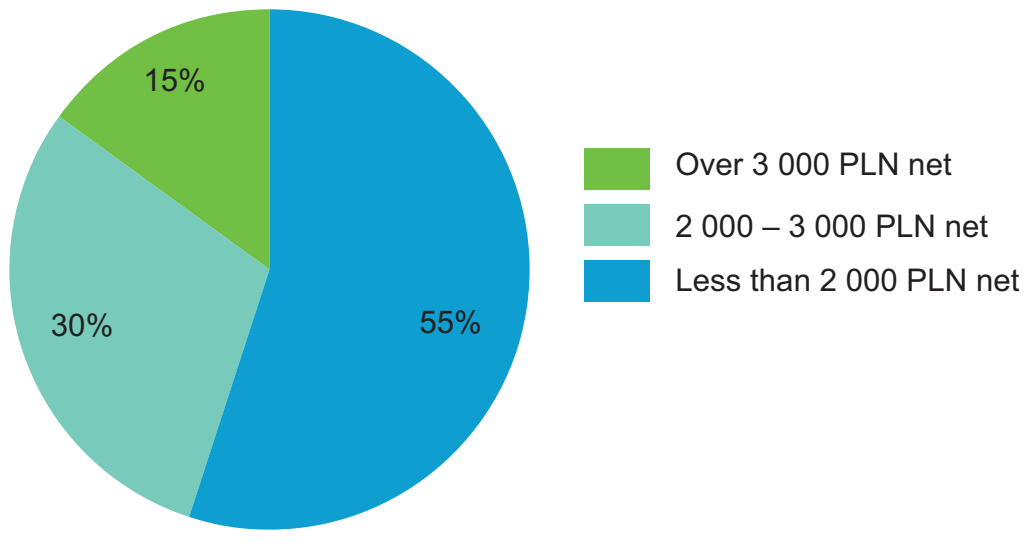

Figure 2. Women earning up to PLN 3,000 net and their dissatisfaction with remuneration

Source: own questionnaire.

The respondents were asked to give a reason for their dissatisfaction with their wage. Most argued that the remuneration is too low in relation to the work and inadequate for their level of responsibility. Another reason was that current earnings do not allow them to satisfy higher-level needs (for example, entertainment, travel, saving). Others commented that the remuneration should also be adequate to the level of education. Note that the earnings of most respondents in the last few years have increased (up to 70 percent of respondents) because

${ }^{6}$ In 2018, the minimum wage in Poland was around PLN 1,530 net, while the average wage was PLN 3,500 net per month. 
of a change of job, a higher position, or promotion in their current job. Most respondents (64 percent) can also count on the support of a partner.

In this part of the survey, we further consider such factors as entertainment, well-being, health, relationships with loved ones, level of security, and personal development. For questions about whether they used various forms of entertainment and recreation over the last five years, 60 percent (302 people) answered in the affirmative. The remaining 40 percent ( 201 people) answered in the negative, explaining that they have no time for such pleasures because of children, work, or lack of money. The next question was intended to identify whether the respondents engage in different activities that affect personal development. As many as 57 percent ( 287 people) do not engage in such activities, primarily because of a lack of time and financial resources ( 42 percent). ${ }^{7}$ Respondents who gave a positive answer were additionally asked to list the types of such activities. The most frequent answers were language workshops and training related to improving their qualifications at work.

Furthermore, women were asked to assess their well-being and health and to express their opinion on relationships with loved ones and their own sense of security. Fully 74 percent (373 people) consider their health and well-being to be good, and only 13 percent ( 65 people) rate them below good (figure 3 ).

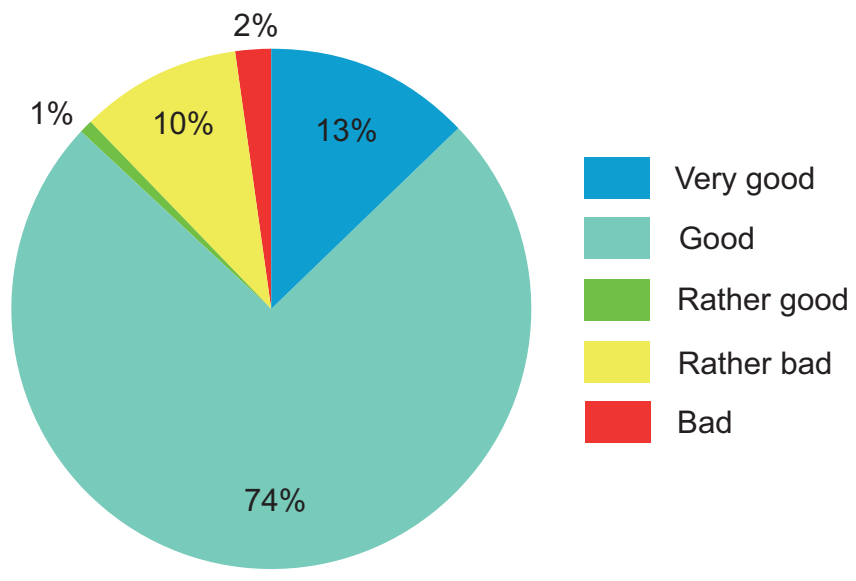

Figure 3. How do you rate your well-being and health?

Source: own questionnaire.

The respondents - as many as 78 percent (645 people) - also spoke positively about relationships with their loved ones. Similarly, a little more than half rated their own level of security as good (56 percent, or 282 people), and 21 percent (106 people) as very good. The survey gave the respondents an extensive definition of security: "Security means a way to ensure survival, reduce uncertainty 
/ risk that threatens the freedom to pursue one's own interests, provide minimal protection against diseases and an unhealthy lifestyle, universal appreciation and respect for human rights."

\section{Summary and conclusions}

Quality of life is a multifaceted concept. Most often it is understood as the fulfillment (contentment, happiness) of a person in many aspects of life, including objective and subjective. Much as in many other countries, Polish women's quality of life is unfavorable in many areas when compared to that of men. Our study used a direct method of testing the quality of life, namely a survey of a randomly selected sample of 503 women mostly with higher education living in a city of over 100,000 residents.

Based on the first part of the survey, we find that women are generally satisfied with their quality of life (only one-third rated it as less than good). According to respondents, earnings, well-being, and health have the most influence on their quality of life. Among other factors, they also mention the feeling of being loved, emotional maturity, equal treatment of women and men, career, promotion, or a happy family.

Women in Poland who earn approximately the national average are satisfied with their earnings. The lowest wages were recorded in the group of persons between nineteen and twenty-five years of age who have higher education. The relatively low wages may be related to the respondents' recent entry into the labor market and little professional experience. Among respondents, 352 declared an increase in their earnings over the past five years, which may explain their positive assessment of their quality of life. In addition, women in Poland mostly use various forms of entertainment, highly assess their health and safety, and are satisfied with close relationships with relatives. Among the barriers limiting their quality of life they mention lack of free time, low wages, and remuneration disproportionate to education.

Women in Poland attach great importance to monetary issues. According to them, earnings are one of the most important factors determining the quality of life, and when talking about personal development they mainly indicate language workshops and training courses related to improving qualifications at work. This state of affairs, we believe, results from Poland's postwar and post-communist history. During the World Wars, women in Poland mainly ran their households, raised their children, and supported fighting men. After the political transformation starting in 1989, although the economy was liberalized, their situation did not change significantly. Although women more often took up employment in higher and better paid positions, they were still not accustomed to leading men and, without taking the risk, decided to work in the lower-paying state sector. Poland's accession to the European Union in 2004 improved their situation. Women began 
to earn more and more often decided to combine professional life with running a household, but discrepancies compared to other countries are still visible (Sielska, 2017, 75, 85, 90).

The historically worse position of Polish women in relation to men has had an impact on their perception of quality of life, such that material factors play a significant role. In addition, looking at the problem more generally (and as confirmed by a study by the World Bank and the European Bank for Reconstruction and Development), although the differences in the level of happiness between Eastern and Western Europe disappeared because of economic development in postcommunist countries, people from countries formerly behind the Iron Curtain still compare their standard of living unfavorably with their western neighbors, despite improvement (Transition Report, 2016).

\section{References}

Akranavičiūtė, D., Ruževičius, J. (2007). Quality of life and its components' measurement. Engineering Economics, 2, 43-48.

Bentham, J. (1958). Wprowadzenie do zasad moralności i prawodawstwa. Warszawa: PWN.

Borys, T. (2001). Jakość życia jako kategoria badawcza i cal nadrzędny. In A. Wachowiak (eds.), Jak żyć? (17-39). Poznań: Wydawnictwo Fundacji Humaniora.

Brock, D. (1993). Quality of health care and medical ethics. In M. Nussbaum, A. Sen (eds.), The Quality of Life (95-132). Oxford: Clarendon Press.

Bruni L., Porta P. (2016). Happiness and quality of life reconciled. In L. Bruni, P. Porta, Handbook of Research Methods and Applications in Happiness and Quality of Life (1-19). Cheltenham, UK: Edward Elgar.

Diener, E., Suh, E. (1997). Measuring quality of life: economic, social, and subjective indicators. Social Indicators Research, 40, 189-216.

Duchin, F. and Sinha, A. (1999). Structural Economics and the Quality of Life. Feminist Economics, $5,2,125-132$.

Edgeworth, F.Y. (1881). Mathematical Psychics: An Essay on the Application of Mathematics to the Moral Science. London: Kegan Paul.

Glatzer, W. (2006). Conditions and Criteria for Improving Quality of Life. In W. Ostasiewicz (eds.), Toward Quality of Life improvement (9-32). Wrocław: Publishing House of the Wrocław University of Economics.

Hajduová, Z., Andrejovský, P., Beslerová, S. (2014). Development of quality of life economic indicators with regard to the environment. Procedia - Social and Behavioral Sciences, 110 (2014), 747-54.

Kasprzyk, B. (2015). Problem pomiaru w ekonomii dobrobytu - poglądy historyczne i współczesne. Nierówności Spoleczne a Wzrost Gospodarczy, 41 (1), 287-95.

Kędzior, Z. (2003). Metodologiczne aspekty badania jakości życia. In J. Karwowski (eds.), Jakość życia w regionie (15-17). Szczecin: Uniwersytet Szczeciński.

Kowalska, M., Marcinkowska, U., Jośko, J. (2010). Satysfakcja z pracy zawodowej a jakość życia kobiet w wieku 45-60 lat w województwie śląskim. Medycyna Pracy, 61 (13), 277-285.

Michoń, P. (2010). Ekonomia szczęścia. Poznań: Wydawnictwo Harasimowicz.

Pareto, V. (1971). Manual of Political Economy. New York: Augustus M. Kelley.

Persky, J. (1992). Retrospectives: Pareto's Law. American Economic Association, 6 (2), 181-92.

Ekonomia - Wroclaw Economic Review 26/, 2020

(C) for this edition by CNS 
Pigou, A.C. (1920). The Economics of the Welfare. London: McMillan.

Sen, A.K. (1970). Collective Choice and Social Welfare. San Francisco: Holden.

Sielska, A. (2017). Dyskryminacja instytucjonalna kobiet na polskim rynku pracy. Warszawa: CeDeWu.

Sompolska-Rzechuła, A. (2013). Jakość życia jako kategoria ekonomiczna. Folia Pomeranae Universitatis Technologiae Stetinensis, 301 (71), 127-40.

Sztumski, J. (2014). Jakość życia jako kategoria socjologiczno-ekonomiczna. Studia Ekonomiczne, $179,21-27$.

Tobiasz-Adamczyk, B. (1999). Jakość życia: zakres badań w perspektywie socjologicznej. Sztuka Leczenia, 5 (3).

Transition Report (2016). Retrived May 30, 2019, from http://2016.tr-ebrd.com/.

Veenhoven, R. (1994). Is happiness a trait? Tests of the theory that a better society does not make people any happier. Social Indicators Research, 32, 101-60.

Włodarczyk, K. (2015). Jakość życia postrzegana przez Polaków w XXI wieku. Konsumpcja i rozwój, 10, 3-16. 